\title{
Article
}

\section{Proton-gradient-transfer acid complexes and their catalytic performance for the synthesis of geranyl acetate}

\author{
Yongle Chen, Shiya Ding, Wentao Zheng, Yiyang Zhang, Youting $\mathrm{Wu}^{*}$, Xingbang $\mathrm{Hu}$ \\ Separation Engineering Research Center, Key Laboratory of Mesoscopic Chemistry of MOE, School of Chemistry and Chemical Engineering, \\ Nanjing University, Nanjing 210093, Jiangsu, China
}

\section{A R T I C L E I N F}

\section{Article history:}

Received 29 August 2016

Accepted 6 October 2016

Published 5 December 2016

\section{Keywords:}

Geranyl acetate

Esterification

Kinetics

Proton gradient transfer

Reaction-induced self-separation

catalyst

\begin{abstract}
A B S T R A C T
Special proton-gradient-transfer acid complexes (PGTACs) in which the bonded protons are not equivalent and have gradients in transfer ability, acidity, and reactivity were reported. The acidity gradient of the protons gave the PGTACs excellent catalytic activity and selectivity in the esterification of terpenols. These PGTACs are "reaction-induced self-separation catalysts" and can be easily reused. The kinetics with PGTACs as catalyst in the esterification of geraniol were also studied for use in engineering design.
\end{abstract}

(C) 2016, Dalian Institute of Chemical Physics, Chinese Academy of Sciences. Published by Elsevier B.V. All rights reserved.

\section{Introduction}

Esters are important chemical intermediates and products in the food, cosmetic and pharmaceutical industries. Acid-catalyzed esterification reactions are the most prevailing methods to produce esters in both industry and academia [1-4]. Strong inorganic and organic acids, such as $\mathrm{H}_{2} \mathrm{SO}_{4}$ and $\mathrm{CF}_{3} \mathrm{SO}_{3} \mathrm{H}$, are well-known catalysts for esterification. These catalysts have good catalytic activity but suffer from the problems of causing equipment corrosion, being difficult to separate from the solution, have low selectivity, give side reactions, and cause environment pollution [5]. To overcome these drawbacks, many novel homogeneous and heterogeneous acid catalysts have been developed, such as special Lewis acid catalysts [6], heteropolyacids [7,8], ionic liquid catalysts [9-15], acidic zeolites [16-18], macroporous polymeric acids [19], sulphated complexes [20-23], acidic resins [24,25], and other solid acids $[26,27]$. Among these catalysts, the acidic complexes formed by the neutralization reaction between Brönsted acids and bases are receiving more attention for their low cost, low corrosiveness and reasonable catalytic activity [2,9,10-12,28-30]. Protonic ionic liquids (PILs) are typical examples of such complexes [2,9-12].

Because there is a lone electron pair on the $\mathrm{N}$ atom of the Brönsted base, the proton of the acid transfers to the $\mathrm{N}$ atom with a large Gibbs free energy change [31,32] during the formation of the PILs cations. As a result, the proton bonds tightly to the Brönsted base and the acid strength is reduced compared to the free acid [33]. However, the catalytic activity of PILs is related to their acid strength [9]. Hence, compared to the free acid used to produce the PILs, the catalytic activity of these PILs in acid-catalyzed reactions are usually weaker.

\footnotetext{
* Corresponding author. Tel: +86-25-89681952; Fax: +86-25-89681953; E-mail: ytwu@nju.edu.cn This work was supported by the National Natural Science Foundation of China $(21376115,21576129)$. DOI: 10.1016/S1872-2067(16)62577-9 | http://www.sciencedirect.com/science/journal/18722067 | Chin. J. Catal., Vol. 37 , No. 12, December 2016
} 

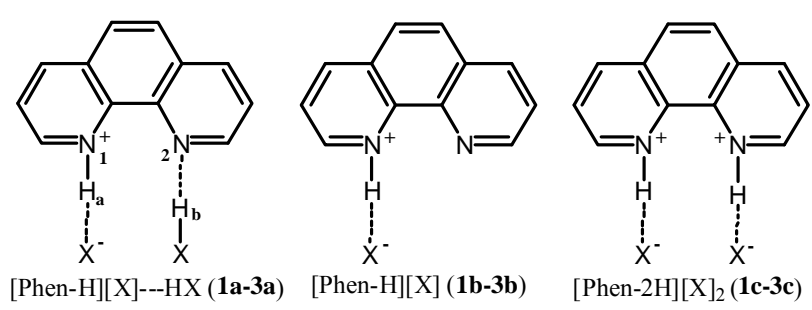

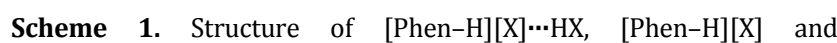
[Phen-2H] $[\mathrm{X}]_{2}$. $\mathrm{X}^{-}=\mathrm{CH}_{3} \mathrm{SO}_{3}{ }^{-}$(1), $\mathrm{HSO}_{4}{ }^{-}$(2), and $\mathrm{CH}_{3} \mathrm{PhSO}_{3}{ }^{-}$(3).

In contrast to these widely known PILs, we reported here a new bonding mode between the Brönsted acid and base. They are called proton gradient transfer acid complexes (PGTACs). The PGTACs were generated by a reaction between phenanthroline (Phen) and acid in 1:2 mole ratio ([Phen-H][X] $\cdots \mathrm{HX}$, 1a-3a in Scheme 1). These complexes are interesting because only one proton $\left(\mathrm{H}_{\mathrm{a}}\right)$ formed a covalent bond with the $\mathrm{N}$ atom of Phen, and another proton $\left(\mathrm{H}_{b}\right)$ formed a hydrogen bond with another $\mathrm{N}$ atom. Furthermore, $\mathrm{Hb}_{\mathrm{b}}$ can transfer between the $\mathrm{N}$ atom and $\mathrm{X}$ anion with a low barrier. That is, the transfer abilities of the $\mathrm{H}_{\mathrm{a}}$ and $\mathrm{H}_{\mathrm{b}}$ protons are different. The PGTACs are a good compromise between the free acid (HX) and [Phen-H][X] when both catalytic activity and selectivity are taken into consideration. In particular, these PGTACs can be easily separated and reused because of the nature of the salts, so a green reaction separation integration is enabled.

\section{Experimental}

\subsection{Materials}

All chemicals were analytical grade and used without any purification. 1,10-Phenanthroline (Phen) was purchased from Sun Chemical Technology (Shanghai) Co. Ltd. Geraniol, acetic anhydride, methylsulfonic acid (MSA), $\mathrm{H}_{2} \mathrm{SO}_{4}$, $p$-toluenesulfonic acid (PTS), and D72 resin were obtained from Jintan Huagong Chemical Research Institute (Jiangsu, China). Lewatit@ K 2620 resin was purchased from Aladdin Industrial Corporation (Shanghai, China). The other alcohols were obtained from Energy Chemical (China) Co. Ltd.

\subsection{Methods}

${ }^{1 \mathrm{H}}$ and ${ }^{13} \mathrm{C}$ NMR spectra were collected on an Agilent DD2 400MR equipment operating at 400 and $100 \mathrm{MHz}$, respectively. The elemental analysis (EA) was obtained using a Heraeus-CHN-O-Rapid analyzer. The ESI MS spectra were determined with a LCQ-fleet ESI Mass Spectrometer. The FTIR spectra of the samples were recorded on a PerkinElmer Spectrum 100 Series FTIR spectrometer with a universal ATR accessory. Thermogravimetry characterization for these PGTACs was carried out on a PerkinElmer Diamond TG/DTA from room temperature to $800{ }^{\circ} \mathrm{C}$ with a heating rate of $10{ }^{\circ} \mathrm{C} / \mathrm{min}$ under $\mathrm{N}_{2}$ atmosphere. An Angilent $8453 \mathrm{UV}$-visible spectrometer was used to determinate the Hammett functions $\left(H_{0}\right)$ of the PGTACs. The experiments were carried out in methanol solution $(2$
mmol/L) of PGTACs and other catalysts at room temperature $\left(25^{\circ} \mathrm{C}\right)$. Dimethyl yellow $\left(\mathrm{p} K_{\mathrm{a}}(\mathrm{I})_{\mathrm{aq}}=3.3\right)$ was used as the indicator $(0.085 \mathrm{mmol} / \mathrm{L})$, and the UV-visible determination was carried out in the range of $200-700 \mathrm{~nm}$.

\subsection{Synthesis and characterization of PGTACs}

To a vigorously stirred ethanol solution (100 mL) of 1,10-phenanthroline (18.02 g, $0.1 \mathrm{~mol})$, ethanol solution (50 $\mathrm{mL}$ ) of sulfuric acid ( $19.60 \mathrm{~g}, 0.2 \mathrm{~mol})$ was added at $0{ }^{\circ} \mathrm{C}$. The mixture was stirred for a further $12 \mathrm{~h}$ at reflux temperature. The ethanol was removed by evaporation to give a reddish liquid. Then, the colored residue was washed with benzene three times and dried in vacuum to give the purified PGTACs 1a. This catalyst was solidified on cooling (yield: 99\%). PGTACs $\mathbf{2 a}$ to $\mathbf{3 b}$ were synthesized similarly to the preparation of PGTACs 1a. The yields of these PGTACs were all above 99\%. The structural maps of $\mathbf{1 a}-\mathbf{3 b}$ are shown in Figure 1.

PGTACs 1a. ${ }^{1} \mathrm{H}$ NMR (400 MHz, DMSO- $\left.d_{6}\right) \delta=9.34(1 \mathrm{H}, \mathrm{d})$, $9.33(1 \mathrm{H}, \mathrm{d}), 9.13(1 \mathrm{H}, \mathrm{d}), 9.10(1 \mathrm{H}, \mathrm{d}), 8.39(2 \mathrm{H}, \mathrm{s}), 8.27(1 \mathrm{H}$, d), $8.25(1 \mathrm{H}, \mathrm{d}), 2.44(6 \mathrm{H}, \mathrm{s}) .{ }^{13} \mathrm{C}$ NMR $\left(100 \mathrm{MHz}, \mathrm{DMSO}-d_{6}\right) \delta=$ 148.22, 141.98, 138.03, 129.77, 127.82, 126.03, 40.37. MS (ESI): $m / z=181.08[\mathrm{M}+\mathrm{H}]^{+}$. Anal. Calcd. for $\mathrm{C}_{14} \mathrm{H}_{16} \mathrm{~N}_{2} \mathrm{O}_{6} \mathrm{~S}_{2}: \mathrm{C}$ 45.16, H 4.30, N 7.53; Found: C 45.14, H 4.31, N 7.55.

PGTACs 3a. ${ }^{1} \mathrm{H}$ NMR (400 MHz, DMSO- $\left.d_{6}\right) \delta=9.33(1 \mathrm{H}, \mathrm{d})$, $9.32(1 \mathrm{H}, \mathrm{d}), 9.12(1 \mathrm{H}, \mathrm{d}), 9.10(1 \mathrm{H}, \mathrm{d}), 8.38(2 \mathrm{H}, \mathrm{s}), 8.26(1 \mathrm{H}$, d), $8.25(1 \mathrm{H}, \mathrm{d}), 7.49(4 \mathrm{H}, \mathrm{d}), 7.13(4 \mathrm{H}, \mathrm{t}), 2.29(6 \mathrm{H}, \mathrm{s}) .{ }^{13} \mathrm{C}$ NMR (100 MHz, DMSO-d $) \delta=147.62,145.29,142.03,137.82$, $137.30,129.58,128.10,127.54,125.77,125.46,20.75$. MS (ESI): $m / z=181.08[\mathrm{M}+\mathrm{H}]^{+}$. Anal. Calcd. for $\mathrm{C}_{26} \mathrm{H}_{24} \mathrm{~N}_{2} \mathrm{O}_{6} \mathrm{~S}_{2}: \mathrm{C}$ 59.54, H 4.58, N 5.34; Found: C 59.50, H 4.63, N 5.30.

PGTACs 1b. ${ }^{1} \mathrm{H}$ NMR (400 MHz, DMSO- $\left.d_{6}\right) \delta=9.31(1 \mathrm{H}, \mathrm{d})$, $9.30(1 \mathrm{H}, \mathrm{d}), 9.06(1 \mathrm{H}, \mathrm{d}), 9.04(1 \mathrm{H}, \mathrm{d}), 8.35(2 \mathrm{H}, \mathrm{s}), 8.21(1 \mathrm{H}$, d), $8.19(1 \mathrm{H}, \mathrm{d}), 2.31(3 \mathrm{H}, \mathrm{s}) .{ }^{13} \mathrm{C}$ NMR $(100 \mathrm{MHz}$, DMSO-d $) \delta=$ $148.09,142.44,137.59,129.94,127.95,126.23,40.18$. MS (ESI): $m / z=181.08[\mathrm{M}+\mathrm{H}]^{+}$. Anal. Calcd. for $\mathrm{C}_{13} \mathrm{H}_{12} \mathrm{~N}_{2} \mathrm{O}_{3} \mathrm{~S}: \mathrm{C}$ 56.52, H 4.35, N 10.14; Found: C 56.55, H 4.35, N 10.13.

PGTACs 3b. ${ }^{1} \mathrm{H}$ NMR (400 MHz, DMSO- $\left.d_{6}\right) \delta=9.32(1 \mathrm{H}, \mathrm{d})$, $9.31(1 \mathrm{H}, \mathrm{d}), 9.09(1 \mathrm{H}, \mathrm{d}), 9.07(1 \mathrm{H}, \mathrm{d}), 8.37(2 \mathrm{H}, \mathrm{s}), 8.24(1 \mathrm{H}$, d), $8.23(1 \mathrm{H}, \mathrm{d}), 2.28(3 \mathrm{H}, \mathrm{s}) .{ }^{13} \mathrm{C}$ NMR $\left(100 \mathrm{MHz}\right.$, DMSO- $\left.d_{6}\right) \delta=$ $148.14,146.14,142.30,138.13,137.85,129.94,128.54,127.94$, 126.17, 125.99, 21.24. MS (ESI): $m / z=181.08[\mathrm{M}+\mathrm{H}]^{+}$. Anal. Calcd. for $\mathrm{C}_{19} \mathrm{H}_{16} \mathrm{~N}_{2} \mathrm{O}_{3} \mathrm{~S}$ : C 64.77, H 4.55, N 7.95; Found: C 64.70, H 4.57, N 8.04. Data for PGTACs $2 \mathbf{a}$ and $\mathbf{2 b}$ have been reported in other being published articles.

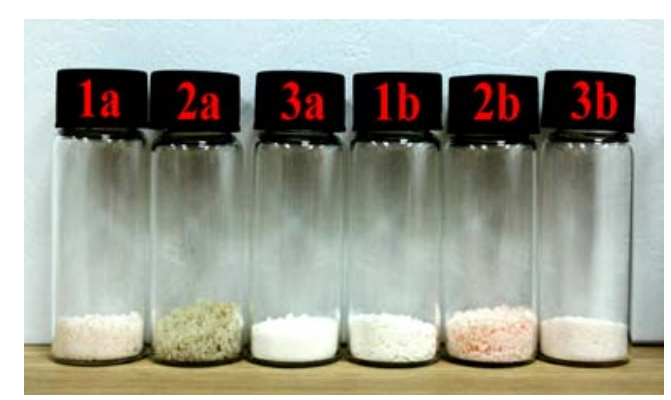

Fig. 1. Prepared PGTACs samples 1a, 2a, 3a, 1b, 2b and $\mathbf{3 b .}$ 


\subsection{Esterification of geraniol}

Geraniol (1.54 g, $0.01 \mathrm{~mol}$ ) and acetic anhydride (1.02 g, $0.01 \mathrm{~mol}$ ) were added to a $100 \mathrm{~mL}$ three neck round bottom flask and heated to a designed temperature. Then $1 \mathrm{a}(0.074 \mathrm{~g}$, $0.2 \mathrm{mmol}$ ) was added to the mixture and stirred at $50{ }^{\circ} \mathrm{C}$ for $2 \mathrm{~h}$. 1a was separated from the reaction system by easy decantation. The yield of geranyl acetate was determined by GC-MS with an internal standard ( $n$-butyl acetate). The proposed mechanism for the reaction of geraniol with acetic anhydride with the use of PGTACs as catalyst is shown in Scheme 2.

\section{Results and discussion}

\subsection{Structure analysis}

In this paper, we focused on the exploration of the novel protonic catalysts. The reaction between Phen and HX 1:1 can generate $[\mathrm{Phen}-\mathrm{H}][\mathrm{X}]$ compounds $(\mathbf{1 b}-\mathbf{3 b})$ that are in fact analogues of PILs, even though the melting points of [Phen-H][X] were a bit high (Table 1). There is still one $\mathrm{N}$ atom with a lone electron pair in [Phen-H][X]. It was a surprise to find that one more $\mathrm{HX}$ can react with $[\mathrm{Phen}-\mathrm{H}][\mathrm{X}]$ to produce the dicationic compounds [Phen-2H][X]2 (Scheme 1, 1c-3c). All the experimental characterization of the 2:1 (acid:Phen) reaction products suggested the formation of complexes (1a-3a) between

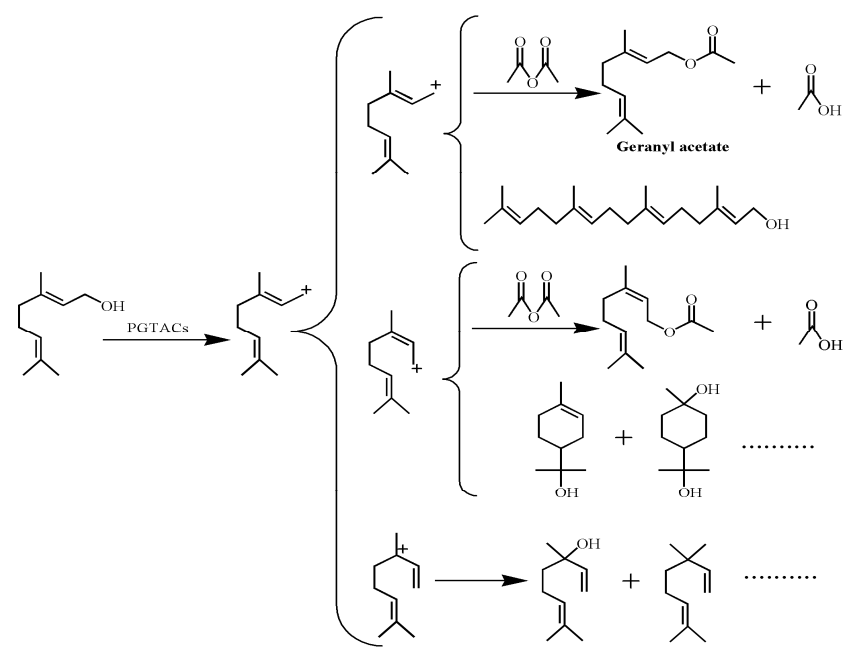

Scheme 2. Suggested mechanism for the reaction of geraniol with acetic anhydride with the use of PGTACs as catalyst.

Table 1

Physical and chemical properties of the catalysts.

\begin{tabular}{lccc}
\hline Catalyst & $T_{\mathrm{m}}{ }^{\mathrm{a}} /{ }^{\circ} \mathrm{C}$ & $T_{\mathrm{d}} \mathrm{b} /{ }^{\circ} \mathrm{C}$ & $H_{0} \mathrm{c}$ \\
\hline $\mathbf{1 a}$ & 62.2 & 300.1 & 2.86 \\
$\mathbf{2 a}$ & 180.6 & 298.3 & 2.81 \\
$\mathbf{3 a}$ & 110.3 & 286.1 & 2.60 \\
$\mathbf{1 b}$ & 103.2 & 299.5 & 4.59 \\
$\mathbf{2 b}$ & 198.6 & 331.9 & 4.23 \\
$\mathbf{3 b}$ & 157.2 & 332.2 & 4.35 \\
$\mathrm{MSA}^{\mathrm{b}}$ & - & - & 2.62 \\
$\mathrm{H}_{2} \mathrm{SO}_{4}$ & - & - & 2.58 \\
$\mathrm{PTS}^{\mathrm{PTS}}$ & - & - & 2.60 \\
\hline
\end{tabular}

${ }^{a}$ Melting point; ${ }^{b}$ Decomposition temperature; ${ }^{c}$ Hammett acidity.
$[$ Phen- $\mathrm{H}][\mathrm{X}]$ and HX. Both the ${ }^{1} \mathrm{H}$ NMR and elemental analysis clearly showed that the complexes were composed of Phen and acid in 1:2 mole ratio. However, the ESI MS analysis for all the products gave $[\mathrm{M}+\mathrm{H}]^{+}=181.1$, revealing that the complexes contain only a single cation $\left([\mathrm{Phen}-\mathrm{H}]^{+}\right)$rather than the di-cation $\left([\mathrm{Phen}-2 \mathrm{H}]^{2+}\right)$. Furthermore, the acid strength of 1a-3a was about two orders of magnitude larger than that of $\mathbf{1 b}-\mathbf{3 b}$ (Table 1), also indicating that the two protons in 1a-3a were not equivalent. That is, the 2:1 (acid:Phen) reaction products were not $[\mathrm{Phen}-2 \mathrm{H}][\mathrm{X}]_{2}$. The melting points of the $2: 1$ products (1a-3a) were close to those of some PILs [9], but obviously lower than those of the corresponding 1:1 products (1b-3b).

To understand why the two protons are not equivalent and explore the structures of 1a-3a, the optimization of the 2:1 (acid:Phen) complexes were performed at the B3LYP/ $6-31++G^{* *}$ level using methanol as solvent. The calculations further confirmed the experimental results that only $\mathrm{H}_{\mathrm{a}}$ formed a covalent bond with the $\mathrm{N}$ atom and $\mathrm{H}_{\mathrm{b}}$ only formed a hydrogen bond with another $\mathrm{N}$ atom. The $\mathrm{N}-\mathrm{H}_{\mathrm{a}}$ and $\mathrm{N}-\mathrm{H}_{\mathrm{b}}$ distances ranged from 1.032 to $1.036 \AA$ and 3.068 to $3.571 \AA$, respectively (Fig. 2).

\subsection{Catalytic performance of the PGTACs}

Geranyl acetate is known as terpenol [34]. The olefin functional groups in terpenols are susceptible to the acids used in the esterification reaction [35]. Strong acids give total conversion but much byproducts, while weak acids exhibit excellent selectivity but poor catalytic activity. In this paper, the two protons in PGTACs gave it an appropriate acidity (1a, $H_{0}=2.86$, Table 2) between a strong acid (MSA, $H_{0}=2.62$, Table 2) and weak acid (1b, $H_{0}=4.59$, Table 2). The PGTACs have both the advantages of strong and weak acids, and gave excellent catalytic activity and selectivity for the esterification of geraniol (Entries 1 and 2, Table 2). Although the reactions catalyzed by

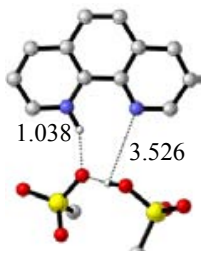

1a $(0.0)$

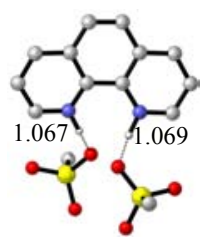

1c $(6.1)$

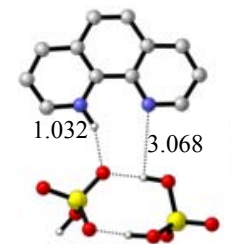

2a $(0.0)$

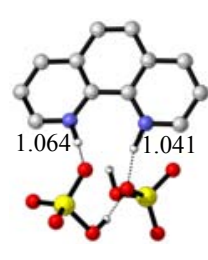

2c $(0.2)$

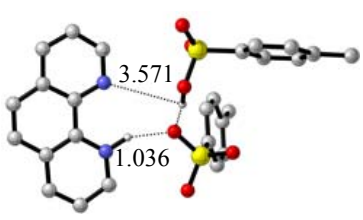

3a $(0.0)$

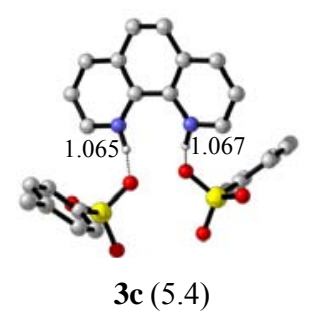

Fig. 2. Optimized structure of $[\mathrm{Phen}-\mathrm{H}]\left[\mathrm{CH}_{3} \mathrm{SO}_{3}\right] \cdots \mathrm{CH}_{3} \mathrm{SO}_{3} \mathrm{H}$ (1a), $[\mathrm{Phen}-\mathrm{H}]\left[\mathrm{HSO}_{4}\right] \cdots \mathrm{H}_{2} \mathrm{SO}_{4}$ (2a), and Phen-H][ $\left.\mathrm{CH}_{3}-\mathrm{Ph}-\mathrm{SO}_{3}\right] \cdots \mathrm{CH}_{3}-\mathrm{Ph}-$ $\mathrm{SO}_{3} \mathrm{H}(\mathbf{3 a})$. All $\mathrm{H}$ atoms of $\mathrm{C}-\mathrm{H}$ are omitted for clarity. The values shown are $\mathrm{N}-\mathrm{H}$ distance in $\AA \AA$. Values in parentheses are relative energy in $\mathrm{kcal} / \mathrm{mol}$. 
Table 2

Catalyst screening for the synthesis of geranyl acetatea.

\begin{tabular}{lcccc}
\hline \\
\hline 1
\end{tabular}

Reaction condition: geraniol $(0.02 \mathrm{~mol})$, acetic anhydride $(0.02 \mathrm{~mol})$, $2 \%(\mathrm{~mol})$ catalyst, temperature $=50^{\circ} \mathrm{C}$.

a Conversion of geraniol determined by GC with $n$-butyl acetate as the internal standard. ${ }^{\mathrm{b}} 20^{\circ} \mathrm{C}$. ${ }^{\mathrm{c}} 0.2 \%$ (mol) catalyst and $20^{\circ} \mathrm{C}$. ${ }^{\mathrm{d}}$ The dosage of the two resins is equal to the amount of $2 \%$ (mol) $\mathbf{1 a}$.

the PILs analogues (1) and $\mathbf{2 b}$ ) gave good selectivity, their catalytic activities were low due to their weak acidity (Entries 3 and 4) [9]. On the contrary, the free acids (MSA and $\mathrm{H}_{2} \mathrm{SO}_{4}$ ) were too active and gave low selectivity even when the reaction temperature was reduced to $20^{\circ} \mathrm{C}$ (Entries 5 and 6). Hence, the PGTACs were good compromises between the free acid HX (strong acid) and the PILs analogues [Phen-H][X] (weak acid).

The widely used homogeneous inorganic and organic acids are very difficult to separate and reuse. Resins have been widely used for many esterification reaction because they are easily separated [24,25]. We tested two resins (D72 and Lewatit $(K 620)$ in the esterification of geraniol and found that these resins were of lower reactivity and poorer selectivity (Entries 7 and 8, Table 2) than that of $\mathbf{1 a}$ with the same catalyst dosage.

To optimize the reaction conditions of PGTACs $\mathbf{1 a}$ in the catalytic reaction of geraniol, the effects of reaction time, temperature and catalyst dosage on the conversion of geraniol and selectivity to geranyl acetate were explored systematically. In Fig. 3, it is shown that the conversion of geraniol increased dramatically in the first $1 \mathrm{~h}$ (to $94.7 \%$ ) and was nearly complete at $2 \mathrm{~h}(99.6 \%)$ in the presence of 1a. It is worthwhile to

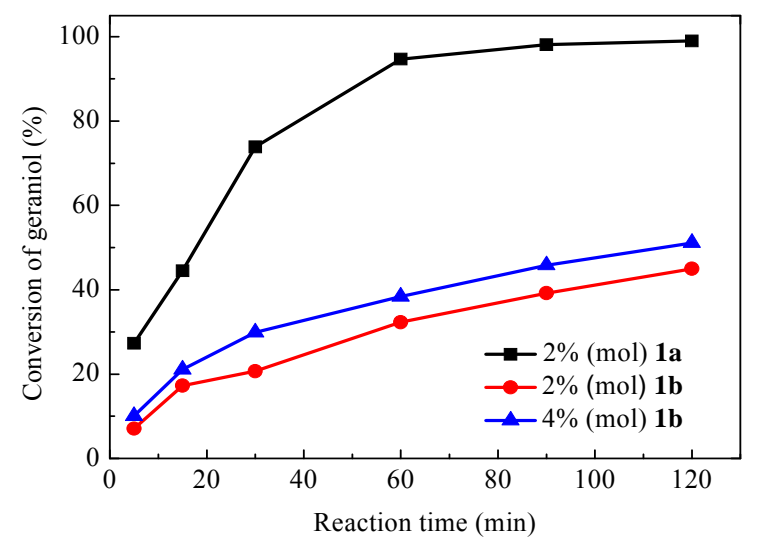

Fig. 3. Conversion versus time for the esterification of geraniol with different catalysts.

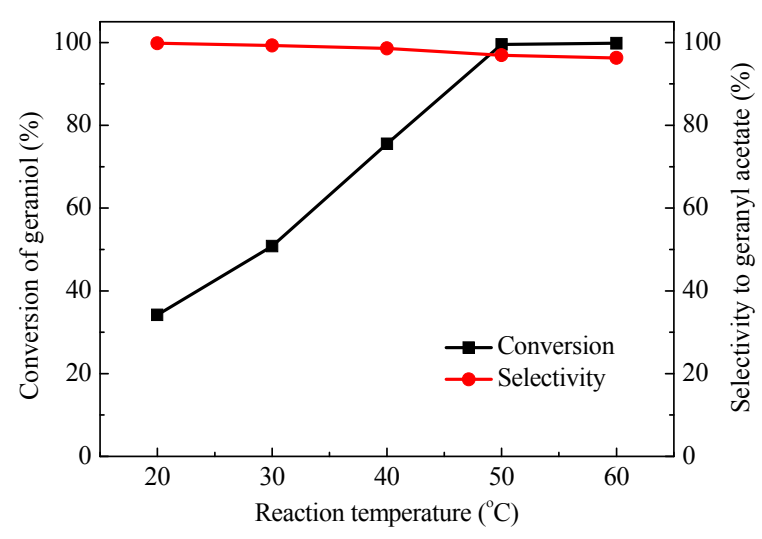

Fig. 4. Effect of reaction temperature on the conversion of geraniol and selectivity to geranyl acetate.

note that the reaction catalyzed by $4 \%$ (mol) $\mathbf{1 b}$ was far slower than that using $2 \%$ (mol) 1a. This reaction data further proved that the two protons in 1a are not equivalent.

The effect of reaction temperature was examined from $20^{\circ} \mathrm{C}$ to $60{ }^{\circ} \mathrm{C}$ with a $1: 1$ molar ratio of geraniol and acetic anhydride to the catalyst dosage of $2 \%(\mathrm{~mol})$ at $2 \mathrm{~h}$. The results are shown in Fig. 4. It was found that the conversion of geraniol increased from $35.2 \%$ to $100 \%$ with increased reaction temperature from 20 to $60{ }^{\circ} \mathrm{C}$, while the selectivity was only slightly decreased (from $99.5 \%$ to $95.7 \%$ ). In addition, the $96.4 \%$ yield of geranyl acetate at $50{ }^{\circ} \mathrm{C}, 0.7 \%$ more than that at $60{ }^{\circ} \mathrm{C}$, illustrated that the optimal reaction temperature was $50{ }^{\circ} \mathrm{C}$.

The effect of catalyst dosage on the conversion of geraniol and selectivity to geranyl acetate was also investigated. The results are illustrated in Fig. 5. The conversion of geraniol increased with the increase of catalyst dosage from $0.5 \%$ (mol) to $2 \%$ (mol), while the selectivity to geranyl acetate remained almost unchanged (98.7\% to $96.9 \%)$. Therefore, an appropriately increased dosage of catalyst $1 \mathbf{a}$ was beneficial to the production of geranyl acetate, and the suggested catalyst dosage is $2 \%$ (mol).

Using 1a as catalyst, we explored the scope of this highly effective reaction for the esterification of different terpenols under the standard conditions (Table 3). Good to excellent yields

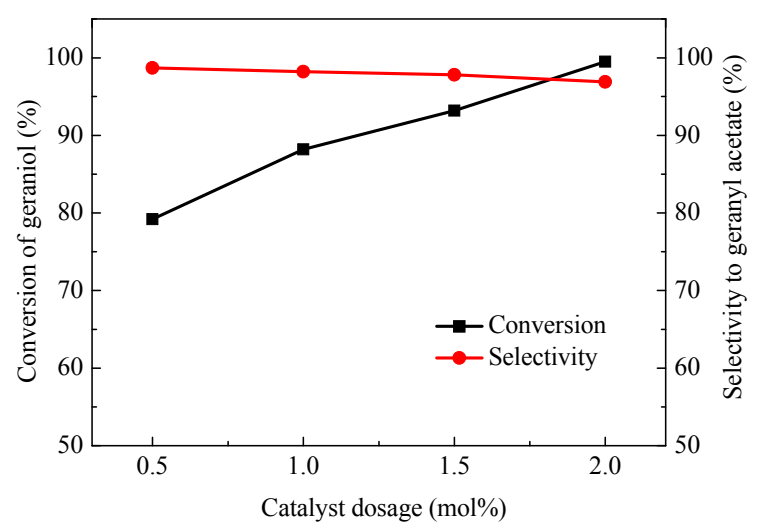

Fig. 5. Effect of catalyst dosage on the conversion of geraniol and selectivity to geranyl acetate. 
of esters were obtained for all the reactions investigated. For easily oxidizable terpenols, such as $6 \mathbf{a}, \mathbf{1 0 a}$ and $11 \mathbf{a}$, the yields ranged from $85 \%$ to $89 \%$. It is beneficial that the reasonable acidity and excellent selectivity of PGTACs could decrease the shedding of $\mathrm{OH}$ groups. As we know, the shedding of $\mathrm{OH}$ groups is the main process to produce water in the esterification of terpenols and acetic anhydride. The hydration products can be easily generated between terpenols and water with the acid as catalyst. Therefore, the PGTACs were appropriate catalysts in the esterification of terpenols and acetic anhydride. The esterification yields of all the other alcohols investigated here were $>95 \%$. PGTAC 1a was super effective for the esterification of aromatic alcohols and the reactions were completed in $2 \mathrm{~h}$ with almost $99 \%$ yield. All the esters produced can be easily separated due to their immiscibility with the catalyst. It is worthwhile to note that all the materials used for the production of PGTAC 1a are very cheap, which would make these esterification reactions of high yield very competitive.

\subsection{The recycle of PGTACs}

It was exciting to find that the PGTACs are "reaction-induced self-separation catalysts" [3]. PGTAC 1a has good solubility in alcohols whereas it is insoluble in esters. Hence, at the end of

Table 3

Esterification of different terpenols catalyzed by $\mathbf{1 a}$.

\begin{tabular}{|c|c|c|c|c|c|}
\hline Entry & Reactant & & $\begin{array}{c}\text { Temperature } \\
\left({ }^{\circ} \mathrm{C}\right)\end{array}$ & $\begin{array}{l}\text { Time } \\
\text { (h) }\end{array}$ & $\begin{array}{c}\text { Yield b } \\
(\%)\end{array}$ \\
\hline 1 & & $5 a$ & 50 & 3 & 95 \\
\hline 2 & & $6 a$ & 50 & 6 & 85 \\
\hline 3 & & $7 a$ & 50 & 4 & $>99$ \\
\hline 4 & & $8 a$ & 60 & 3 & $>99$ \\
\hline 5 & & $9 a$ & 50 & 3 & $>99$ \\
\hline 6 & & $10 a$ & 40 & 4 & 89 \\
\hline 7 & & 11a & 40 & 5 & 89 \\
\hline 8 & & $12 a$ & 30 & 2 & 98 \\
\hline 9 & & 13a & 50 & 2 & $>99$ \\
\hline 10 & & $14 a$ & 50 & 2 & $>99$ \\
\hline 11 & & $15 a$ & 50 & 2 & $>99$ \\
\hline 12 & & $16 a$ & 50 & 2 & 98 \\
\hline
\end{tabular}

Reaction conditions: alcohol ( $0.02 \mathrm{~mol})$, acetic anhydride $(0.02 \mathrm{~mol}), \mathbf{1 a}$ ( $0.4 \mathrm{mmol})$. a Determined by GC with $n$-butyl acetate as the internal standard.

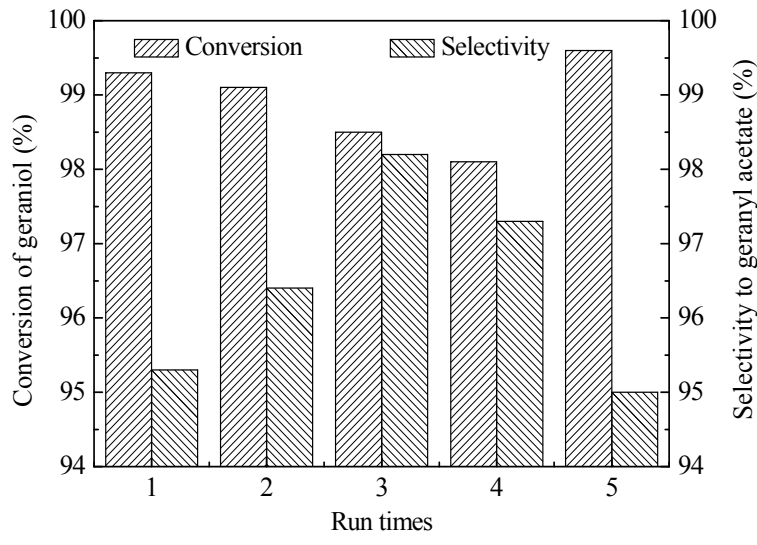

Fig. 6. Recycling of catalyst 1a in the esterification of geraniol.

the reaction, a liquid-liquid biphase was formed and the heavy phase contained catalyst 1a. The heavy phase can be used as catalyst directly without any treatment. The ${ }^{1} \mathrm{H}$ NMR of recycled 1a showed that there was little anionic loss. After regeneration of $1 \mathbf{a}$ by reacting with a small amount of acid at the fourth cycle, catalyst 1a can be regenerated and reused for at least 5 cycles without significant loss of catalytic activity (Fig. 6).

\subsection{Kinetics study of the esterification of geraniol with the use of PGTACs as catalyst}

For future process design, the kinetics with PGTACs in the esterification of geraniol was also investigated. The kinetic study was carried out under the above conditions with the use of $1 \mathbf{a}$ as catalyst. From the consideration of the generation of byproducts, the main reaction can be expressed as:

$$
\begin{aligned}
& \text { Geraniol + Acetic anhydride } \longrightarrow k_{1} \longrightarrow \text { Geranyl acetate + Acetic acid }
\end{aligned}
$$

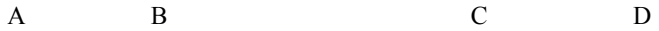

$$
\begin{aligned}
& \text { Geraniol } \stackrel{k_{2}}{\longrightarrow} \text { By-products }
\end{aligned}
$$

Here, a widely used pseudohomogeneous (PH) model $[36,37]$ was used to describe the kinetics of the esterification of geraniol catalyzed by PGTACs 1a. Combining reactions (1) and (2), we can express the rate equation of geranyl acetate, byproducts and geraniol as:

$$
\begin{aligned}
\mathrm{d} C_{\mathrm{C}} / \mathrm{d} t & =k_{1} C_{\mathrm{A}} C_{\mathrm{B}} \\
\mathrm{d} C_{\mathrm{E}} / \mathrm{d} t & =k_{2} C_{\mathrm{A}} \\
-\mathrm{d} C_{\mathrm{A}} / \mathrm{d} t & =k_{1} C_{\mathrm{A}} C_{\mathrm{B}}+k_{2} C_{\mathrm{A}}
\end{aligned}
$$

Using Eqs. (3)-(5), the reaction rate constants $k_{1}$ and $k_{2}$ can be estimated from the experiment data. The results are listed in Table 4 . The values of $k_{1}$ and $k_{2}$ increased notably with the increasing temperature. In addition, the comparison of the experimental and calculated conversion of geraniol was also studied (Fig. 7). It illustrated that the PH model is a good kinetic model for the esterification of geraniol with PGTACs 1a as catalyst.

The activation energy $\left(E_{\mathrm{a}}\right)$ is also an important factor that determines the catalytic ability of the catalyst in the esterification of geraniol. From the reaction rate constants $k_{1}$ and $k_{2}$ at different temperatures, $E_{\mathrm{a}}$ and the pre-exponential factors can 
Table 4

Reaction rate constants at different temperatures.

\begin{tabular}{lcc}
\hline Temperature $\left({ }^{\circ} \mathrm{C}\right)$ & $k_{1}\left(10^{3} \mathrm{~kL} /(\mathrm{mol} \cdot \mathrm{min})\right)$ & $k_{2}\left(10^{3} \mathrm{~min}^{-1}\right)$ \\
\hline 30 & 68.7 & 3.5 \\
40 & 197.9 & 6.1 \\
50 & 986.4 & 29.0 \\
60 & 1041.1 & 46.2 \\
\hline
\end{tabular}

Reaction conditions: Catalyst used for the kinetic study was 1a, catalyst loading was $2 \%$ (mol), molar ratio of geraniol to acetic anhydride was $1: 1$, and reaction time was $2 \mathrm{~h}$.

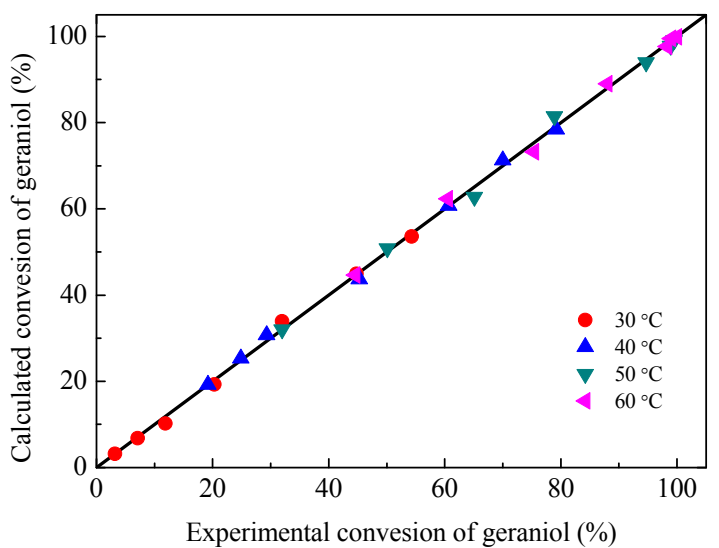

Fig. 7. Comparison of the experimental and calculated conversion of geraniol at different temperatures.

be calculated using the Arrhenius law (Eq. (6)), written as Eq. (7). The linear fit between $\ln k$ and $1 / T$ is shown in Fig. 8.

$$
\begin{aligned}
k & =A \mathrm{e}^{-E_{\mathrm{a}} / R T} \\
\ln k & =\ln A-E_{\mathrm{a}} / R T
\end{aligned}
$$

The activation energies $E_{\mathrm{a} 1}$ and $E_{\mathrm{a} 2}$ and pre-exponential factors $A_{1}$ and $A_{2}$ were 72.36 and $79.68 \mathrm{~kJ} / \mathrm{mol}$, and $2.23 \times 10^{11}$ and $1.60 \times 10^{11}$, respectively. The rate constants were written as:

$$
\begin{aligned}
& k_{1}=2.23 \times 10^{11} \exp \left(-72.36 \times 10^{3} / R T\right) \\
& k_{2}=1.60 \times 10^{11} \exp \left(-79.68 \times 10^{3} / R T\right)
\end{aligned}
$$

The lower activation energy of the side reaction (Eq. (2)) than that of the primary reaction (Eq. (1)) implied that a low temperature is beneficial for the synthesis of geranyl acetate, while an elevated temperature can generate more byproducts.

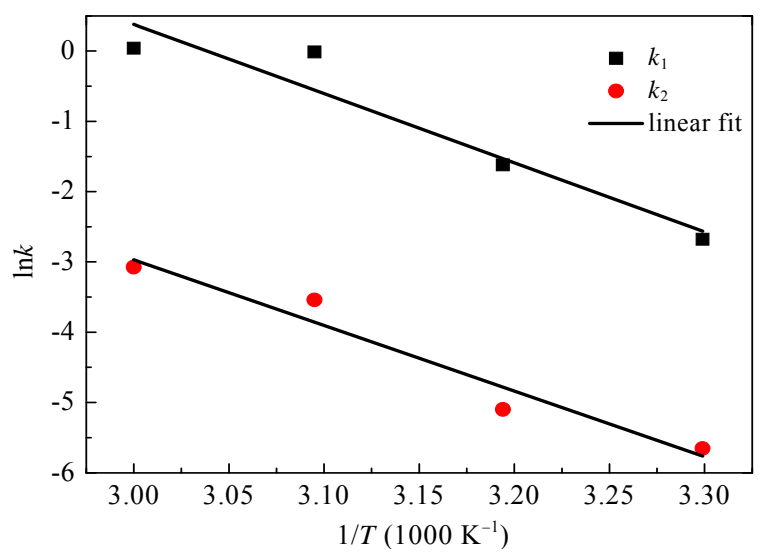

Fig. 8. Arrhenius plots for the esterification of geraniol with acetic anhydride.

\section{Conclusions}

Reactions between acid and Phen in the mole ratio of 2:1 generated special proton-gradient-transfer acid complexes (PGTACs) where the two protons are not equivalent and have gradients in transfer ability, acidity, and reactivity. The PGTACs gave excellent catalytic activity and selectivity for esterification with a series of terpenols as substrate. The PGTACs are a good compromise between strong and weak acids from the aspect of activity. These PGTACs are "reaction-induced self-separation catalysts" and can be easily reused. The advantages of the PGTACs in catalytic activity, selectivity, separation, and price are attractive for use in the esterification reactions in industry.

\section{References}

[1] A. C. Cole, J. L. Jensen, I. Ntai, K. L. T. Tran, K. J. Weaver, D. C. Forbes, J. H. Davis Jr, J. Am. Chem. Soc., 2002, 124, 5962-5963.

[2] A. Sakakura, K. Kawajiri, T. Ohkubo, Y. Kosugi, K. Ishihara, J. Am. Chem. Soc., 2007, 129, 14775-14779.

[3] Y. Leng, J. Wang, D. R. Zhu, X. Q. Ren, H. Q. Ge, L. Shen, Angew. Chem. Int. Ed., 2008, 121, 174-177.

[4] F. J. Liu, L. Wang, Q. Sun, L. F. Zhu, X. J. Meng, F. S. Xiao, J. Am. Chem. Soc., 2012, 134, 16948-16950.

[5] J. Otera, J. Nishikido, Esterification: Methods, Reactions, and Applications, 2nd ed., Wiley-VCH, New York, 2010.

[6] Y. Kita, Y. Nishii, T. Higuchi, K. Mashima, Angew. Chem. Int. Ed., 2012, 51, 5723-5726.

[7] S. H. Zhu, X. Q. Gao, F. Dong, Y. L. Zhu, H. Y. Zheng, Y. W. Li, J. Catal., 2013, 306, 155-163.

[8] M. Kuzminska, T. V. Kovalchuk, R. Backov, E. M. Gaigneaux, J. Catal., 2014, 320, 1-8.

[9] T. L. Greaves, C. J. Drummond, Chem. Rev., 2008, 108, 206-237.

[10] D. J. Tao, Y. T. Wu, Z. Zhou, J. Geng, X. B. Hu, Z. B. Zhang, Ind. Eng. Chem. Res., 2011, 50, 1989-1996.

[11] D. J. Tao, X. M. Lu, J. F. Lu, K. Huang, Z. Zhou, Y. T. Wu, Chem. Eng. J., 2011, 171, 1333-1339.

[12] C. Chiappe, S. Rajamani, F. D’Andrea, Green Chem., 2013, 15, 137-143.

[13] H. P. Zhu, F. Yang, J. Tang, M. Y. He, Green Chem., 2003, 5, 38-39.

[14] P. Lozano, J. M. Bernal, A. Navarro, Green Chem., 2012, 14, 3026-3033.

[15] H. Wan, C. Chen, Z. W. Wu, Y. G. Que, Y. Feng, W. Wang, L. Wang, G. F. Guan, X. Q. Liu, ChemCatChem., 2015, 7, 441-449.

[16] T. V. Kovalchuk, J. N. Kochkin, H. Sfihi, V. N. Zaitsev, J. Fraissard, J. Catal., 2009, 263, 247-257.

[17] J. Bedard, H. Chiang, A. Bhan, J. Catal., 2012, 290, 210-219.

[18] C. Gonzalez-Arellano, R. A. D. Arancon, R. Luque, Green Chem., 2014, 16, 4985-4993.

[19] M. Minakawa, H. Baek, Y. M. A. Yamada, J. W. Han, Y. Uozumi, Org. Lett., 2013, 15, 5798-5801.

[20] D. C. Boffito, V. Crocella, C. Pirola, B. Neppolian, G. Cerrato, M. Ashokkumar, C. L. Bianchi, J. Catal., 2013, 297, 17-26.

[21] J. M. Fraile, E. Garcia-Bordeje, E. Pires, L. Roldan, J. Catal., 2015, 324, 107-118.

[22] C. Poonjarernsilp, N. Sano, N. Sawangpanich, T. Charinpanitkul, H. Tamon, Green Chem., 2014, 16, 4936-4943.

[23] C. C. Huang, C. J. Yang, R. J. Gao, N. C. Wang, C. L. Chen, J. S. Chang, Green Chem., 2015, 17, 3609-3620.

[24] M. Kouzu, A. Nakagaito, J. S. Hidaka, Appl. Catal. A, 2011, 405, 36-44. 


\title{
Graphical Abstract
}

Chin. J. Catal., 2016, 37: 2114-2121 doi: 10.1016/S1872-2067(16)62577-9

\section{Proton-gradient-transfer acid complexes and their catalytic performance for} the synthesis of geranyl acetate

Yongle Chen, Shiya Ding, Wentao Zheng, Yiyang Zhang, Youting Wu*, Xingbang Hu* Nanjing University

The esterification of geraniol was catalyzed by PGTACs with nonequivalent protons. The PGTACs exhibited excellent catalytic activity and selectivity in the synthesis of geranyl acetate and were characterized as "reaction-induced self-separation catalysts".

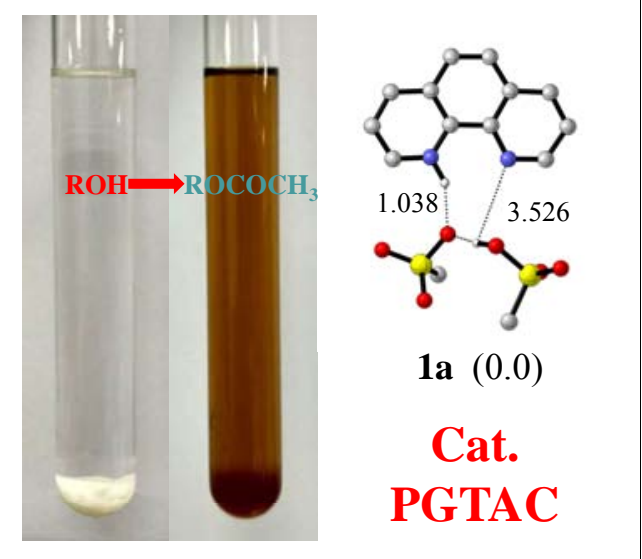

[25] A. K. Purohit, A. Kumar, V. Singh, R. Goud, R. Jain, D. K. Dubey, Tetrahedron Lett., 2014, 55, 6844-6846.

[26] M. G. Kulkarni, R. Gopinath, L. C. Meher, A. K. Dalai, Green Chem., 2006, 8, 1056-1062.

[27] Z. H. Zhang, K. Dong, Z. B. Zhao, ChemSusChem., 2011, 4, 112-118.

[28] K. Ishiara, S. Nakagawa, A. Sakakura, J. Am. Chem. Soc., 2005, 127, 4168-4169.

[29] T. Funatomi, K. Wakasugi, T. Misaki, Y. Tanabe, Green Chem., 2006, 8, 1022-1027.

[30] S. Q. Zhan, X. C. Tao, L. Z. Cai, X. H. Liu, T. P. Liu, Green Chem., 2014, $16,4649-4653$

[31] J. P. Belieres, C. A. Angell, J. Phys. Chem. B, 2007, 111, 4926-4937.
[32] K. Fumino, V. Fossog, K. Wittler, R. Hempelmann, R. Ludwig, Angew. Chem. Int. Ed., 2013, 52, 2368-2372.

[33] L. Zhang, L. He, C. B. Hong, S. Qin, G. H. Tao, Green Chem., 2015, 17, 5154-5163.

[34] M. Sato, K. Matsushima, H. Kawanami, Y. Ikuhsima, Angew. Chem. Int. Ed., 2007, 46, 6284-6288.

[35] R. H. Qiu, Y. Y. Zhu, X. H. H. Xu, Y. H. Li, L. L. Shao, X. F. Ren, X. T. Cai, D. L. An, S. F. Yin, Catal. Commun., 2009, 10, 1889-1892.

[36] A. K. Kolah, N. S. Asthana, D. T. Vu, C. T. Lira, D. J. Miller, Ind. Eng. Chem. Res., 2008, 47, 5313-5317.

[37] P. E. J. Babu, K. Sandesh, M. B. Saidutta, Ind. Eng. Chem. Res., 2011, 50, 7155-7160.

\section{质子梯度转移酸性复合物及其在乙酸香叶酯合成中的催化能力}

\author{
陈永乐，丁诗雅，郑文涛，张艺扬，吴有庭"，胡兴邦 \\ 南京大学化学化工学院介观化学教育部重点实验室分离工程研究中心, 江苏南京210093
}

摘要: 萜烯酯是一类重要的化学中间体和产品, 广泛应用于香料、食品和医药等领域. 酸催化的酯化反应是目前工业合成 萜烯酯最流行的反应之一. 已有用于合成萜烯酯催化剂的报道, 并且大多数催化剂具有较高的催化活性, 但多数催化剂没 有在催化活性、选择性、稳定性和回收性等综合性能上表现出突出优势. 质子型离子液体具有结构可调、易合成及易与 产物分离的特点, 被认为是酯化反应的绿色催化剂和分离剂. 早期的质子型离子液体催化酯化研究主要集中在低碳链饱 和有机酸酯的合成, 对于易氧化的萜烯醇酯化研究较少. 因为Brönsted碱上的 N原子含有一个孤对电子, 在质子型离子液体 阳离子形成的过程中, 酸上的质子传递到这个 $\mathrm{N}$ 原子上时会伴随着较大的吉布斯自由能改变. 这个质子与Brönsted碱紧紧 键合着, 并使其酸性与游离酸相比减弱. 众所周知, 离子液体的催化活性强烈依赖于其酸强度. 所以与游离酸相比, 质子型 离子液体在酯化反应中的催化活性常常被削弱.

本课题组合成了一类新型的“质子梯度转移酸性复合物(PGTACs)”催化剂, 通过核磁共振、质谱、红外光谱及元素分析 等表征方法, 发现其具有有别于常规质子型离子液体的键合模型, 即同时具有一个 $\mathrm{N}-\mathrm{H}$ 共价键和一个 $\mathrm{N} \cdots \mathrm{H}$ 氢键. 这主要是 由于阳离子 1,10 -邻菲罗啉具有高度的对称结构, 且阳离子上的两个 $\mathrm{N}$ 原子位置较近. 当第一个酸上的质子与碱上的第一个 $\mathrm{N}$ 原子键合后会对第二个酸上的质子与碱上的第二个 $\mathrm{N}$ 原子的键合造成较大的空间位阻, 从而使后者以氢键键合方式存在. 此外, 为了进一步了解键合的两个质子的差异性, 我们通过理论计算对其结构进行了优化, 同样证明了 $\mathrm{N}-\mathrm{H}$ 共价键和 $\mathrm{N} \cdots \mathrm{H}$ 氢键的存在, 并得到它们的键长分别为 $1.032-1.036 \AA$ 和3.068-3.571 $\AA$.

本文对PGTACs的催化能力进行了系统研究, 发现该类催化剂兼具强酸催化剂的高催化活性和弱酸催化剂的高选择性 两方面优势, 可选择性地高效催化合成乙酸香叶酯. 当催化剂加入量为 $2 \%$ 摩尔分数, 反应时间为 $2 \mathrm{~h}$, 反应温度为 $50{ }^{\circ} \mathrm{C}$ 时, 香叶醇转化率和乙酸香叶酯选择性分别高达 $99.5 \%$ 和 $96.9 \%$; 而对于易氧化的萜烯酯(如乙酸芳樟酯、乙酸- $\alpha$-松油酯和乙酸 -4-松油酯等)仍有高于 $85 \%$ 的收率. 此外, 研究还发现PGTACs催化剂是一类反应诱导自分离催化剂, 反应初期可快速溶于 
反应体系中形成均相, 反应结束后自动与产物分离, 形成液液双相. 此反应过程不仅有效解决了固体催化剂的传质阻力限 制, 还强化了反应, 实现了反应与分离的耦合. 最后, 我们采用拟均相模型(PH model)对实验数据进行了拟合, 为后续过程 设计提供了宝贵的基础数据.

关键词: 乙酸香叶酯; 酯化; 动力学; 质子梯度转移; 反应诱导自分离催化剂

收稿日期: 2016-08-29. 接受日期: 2016-10-06. 出版日期: 2016-12-05.

*通讯联系人. 电话: (025)89681952; 传真: (025)89681953; 电子信箱: ytwu@nju.edu.cn

基金来源：国家自然科学基金(21376115, 21576129).

本文的英文电子版由Elsevier出版社在ScienceDirect上出版(http://www.sciencedirect.com/science/journal/18722067). 